\title{
THE LENS, FRAMES AND PATTERNS OF UKRAINIANS: HOW PERCEPTION OF THREAT AND RISK DETERMINES BEHAVIOR IN THE COVID-19 SITUATION
}

\author{
LARYSA KLYMANSKA \\ Department of Sociology and Social Work, \\ Lviv Polytechnic National University, Lviv, Ukraine \\ Konovaltsia 4, Lviv, Ukraine \\ Email: larysa_kl@ukr.net \\ ORCID ID: https://orcid.org/0000-0002-3693-7503 \\ MARYNA KLIMANSKA \\ Faculty of Philosophy, Department of Psychology, \\ Ivan Franko National University of Lviv \\ Universytetska 1, Lviv, Ukraine \\ E-mail: marina.klimanska@gmail.com \\ ORCID ID: https://orcid.org/0000-0002-3047-2346 \\ INNA HALETSKA \\ Faculty of Philosophy, Department of Psychology, \\ Ivan Franko National University of Lviv \\ Universytetska 1, Lviv, Ukraine \\ E-mail: innahaletska@gmail.com \\ ORCID ID: https://orcid.org/0000-0002-9319-2229
}

\begin{abstract}
Aim. Identification and construction of the typology of individual ideas about the perception of the risk posed by COVID-19 and potential impact of individual ideas on behavioural human intentions. Risk perception is viewed as a social construct.

Methods. The subject matter of analysis consists of 91 transcripts of semi-structured interviews subjected to thematic analysis (Braun \& Clarke, 2006). On the basis of categories identified through thematic analysis a frame was created, through which an individual perceives the threat posed by COVID-19, while configuration of different subcategories shaped up four types of perception, used for data categorisation.

Results and conclusion. Analysis of the results enabled us to outline the very structure of a frame for the assessment of the risk posed by COVID-19, including seven
\end{abstract}


categories, as well as to outline several typical frames in risk perception, which are traced in the informants' consciences and are manifested in the intentions of behavioural responses to threat, viz.: potential danger (virtual risk); risk as a potential threat; uncertain risk; risk as a real threat.

Research restrictions. The restrictions in the research done include impossibility of regulating the selection of informants, since interviews were conducted under quarantine conditions, therefore the choice of informants was made with constraints.

Practical application. Clarification of risk perception in the conditions of pandemic may enable health care representatives to more efficiently communicate with the public.

Originality. The research was done in the quarantine period, thus it reflects real worries and opinions of informants under the threat of COVID-19. Implementation of the research using qualitative methods ensured focusing on subjective peculiarities of risk perception.

Conclusions: Typology of ideas, frames about risk in the conditions of the COVID19 pandemic requires further clarifications and validation within a qualitative research.

Key words: pandemic, Covid-19, ideas of risk, virtual risk, risk as a potential threat, uncertain risk, uncertain danger, risk as a real threat, qualitative research, preventive health behaviour.

\section{PROBLEM STATEMENT}

$\mathrm{T}$ he COVID-19 pandemic vividly demonstrates the effect of human factors on what is happening in the world. Rapid virus spread became possible due to the achievements of civilisation due to opportunities for humans to move across borders and continents, human striving to embrace the whole world by traveling are concerned, and, at the same time, the inability of humans to objectively assess the situation and rationally predict its development as well as reorganise life style to reduce the risks of available threats. Human irrationality which gets manifested specifically and unexpectedly in the situation of uncertainty causes unpredictability of the epidemic situation development.

Understanding of human behaviour is the key to understanding the causes of the COVID-19 pandemic and selection of the ways to mitigate its consequences in real time. (Behaviour fuels, and fights, pandemics, 2020). Susan Erikson, a medical anthropologist who was in Sierra Leone in 2014 during the Ebola outbreak stresses the striking similarity between the first days of the COVID-19 pandemic and the Western African outbreak of Ebola: people are reluctant to quickly perceive and to change their life style (Erikson, 2020). George A. Soper, analysing the lessons of the pandemic Spanish flu 101 years ago, points out three main factors that prevent stamping out of the epidemic: 1) people underestimate the risks they run; 2) closing oneself off in rigid isolation to protect others runs counter to human nature, and 3) people often unconsciously act in the way to increase danger for themselves and for others (Soper, 1919). It seems that core problems do not change through centuries and continents, history and experience do not teach us a lot, while minor differences in the epidemic situation development, introduction of preventive measures and their efficiency in different countries are situationally caused by social and cultural factors. 
The analytical review of 253 studies of the epidemics of 20th and 21st centuries made by Jay J. Van Bavel and colleagues (Bavel et al., 2020) outlines a number of psychological as well as social and psychological aspects determining the significance of social and behavioural sciences for overcoming the COVID-19 pandemic that has caused a large-scale global crisis in health care, has become a real threat for people's health and life, as well as economic stability of the world, traditional lifestyle and quality of life. Perception of threat, transforming through the prism of beliefs, under the effect of arbitrary and purposeful disinformation and fake information, reinforced by prospectless thinking, lead to conclusions in the style of the conspiracy theory and intensify the experiencing of threat and risks, the sense of catastrophe and panic. Prejudices and discrimination, social norms and social inequality, political polarisation as well as social isolation determine behaviour of individuals, social groups and communities, intensifying unpredictability of the epidemic situation development.

In the absence of pathogenetic drug treatment and vaccination it is possible to influence the COVID-19 pandemic only through mass and rapid changes in the behaviour (Betsch, 2020), therefore, it is these factors and mechanisms that come to be in the focus of research as the problem of primary importance. However, compliance with preventive behaviour normally is rather problematic due to the special nature of risk perception (Oosterhoff \& Palmer, 2020). A wide-spread assumption that knowledge and certainty of people as far as risk is concerned determines how they will perceive it is based on the rational approach, by the logic of which individuals make decisions on the basis of assessment of potential losses and benefits. However, decisions are often passed not on the basis of rational approaches, but on the basis of heuristics, for example, availability heuristic (Kahneman, Slovic, \& Tversky, 1982) that presupposes that availability/knownness of information, its memorability constitutes a proof of its popularity. Information about the virus changes into a mixture of controversial data, opinions, and assumptions. Some people simply reject the pandemic (Stanley, Barr, Peters, \& Seli, 2020), some just don't treat the risk for their life and health seriously, but rather perceive the risk as an abstract one, at the level of "that cannot happen to $\mathrm{me}^{\prime \prime}$, becoming the victims of the mistake of prejudice, optimism (Sharot, 2011). That is confirmed by the data of the first sociological studies in Ukraine: $87 \%$ of Ukrainians consider virus spread to be a threat. And only half of Ukrainians admit that the disease may come to their family (Sociological Group "Rating", 2020). The studies in Ukraine, made via the social media Facebook, show that only $14 \%$ of respondents feel the high level of the threat of being infected COVID-19 (Haletska, Klymanska, \& Klimanska, 2020). The search of strategies for overcoming this multiplicity in the perception of the pandemic must be the crucial task for the planning and implementation of efficient communicative health care campaigns.

Though the risk by itself is objective, independent of the subject, it may be determined as a product of the objective value of consequences and their 
objective likelihood (Lupton, 1999), going through the lens of perception of a specific social subject (who may have an inadequate perception, overestimate or underestimate the likelihood of occurrence or the value of negative consequences). The risk turns into a social construct, while perception of the COVID19 risk is a social construct of a special nature, since event-related importance of the pandemic drastically changes available social order. It is very difficult to trace such contradictions using traditional quantitative research methods. Qualitative methods open up new prospects for the identification of hidden aspects and are of special importance for express assessment (Johnson \& Vindrola-Padros, 2017).

Quantitative methods, due to their open nature and the focus not just on "What", but also on "How," allow us to understand what the sense of health, threat, disease, risk, etc. for people is. Michelle Teti, Enid Schatz, \& Linda Liebenberg point out five important aspects of the benefits of using qualitative methods in the research of pandemics: 1) Health-related behaviour does not always fit into epidemiological models, since it is limited by many different complex psychological, cultural, and social factors. 2 ) Vulnerability of people to diseases is determined not just biologically, but socially as well, therefore, qualitative methods may help shed some light on the needs of some marginalised and specific groups.3) Unexpected results and unexpected conclusions are important for the study of the causes and for the development of anti-epidemic strategies. 4). Peculiarities of medical aid provision, identified due to the application of qualitative methods in the studies of H1N1, SARS, EVD epidemics. 5) Readiness and interest of communities (people), based on people's perceptions of the possible restrictive effect of introduced measures, quarantine, etc. on important and significant spheres of life. Therefore, qualitative methods may play a key role in the understanding of human behaviour during such pandemics as COVID-19 for developing effective decisions and strategies (Teti, Schatz, \& Liebenberg, 2020).

In the context of wide-spread prejudices and ideas it is important to understand how people assess their own risk of contracting the virus. Understanding of risk perception frames may considerably promote an efficient virus management campaign, overcoming the obstacles of subjective treatment of the problem. Since the crisis requires large-scale changes in behaviour and imposes a considerable psychological load on people, the effort of social and behavioural sciences may be used to help align human behaviour with recommendations given by epidemiologists and health care experts.

The aim of the research was to identify and build the typology of individual ideas about perception of risk posed by COVID-19 as well as potential impact of individual ideas on behavioural intentions of individuals. And risk perception was considered as a social construct. 


\section{RESEARCH METHODOLOGY}

In this paper a number of research questions related to individual ideas about the risk of contracting COVID-19 were raised:

- How does individual perception of the situation with coronavirus (the risk of being infected, specific peculiarities of the virus) affect projection of behaviour in crisis conditions? (risk perception)

- How does individual perception and behaviour depend on the sources of information about coronavirus and correlate with the credibility of those sources of information? (sources of information about COVID-19)

- What is the treatment of quarantine-related behavioural restrictions? Do people change their behaviour in the situation when there is a risk of falling ill? (behavioural response aimed at coming to grips with the threat)

- How is the future projected - own future, the future of the state, society after the pandemic? (expectations about the future in own life and in the society)

The survey was conducted during the quarantine announced in Ukraine using the method of semi-structured interview with open-ended questions. Assistance in the interview holding was provided by the students of the Department of Sociology and Social Work of Lviv Polytechnic National University, as well as the students of the Department of Psychology of Ivan Franko National University of Lviv. The data was collected in the period from March 24 to April 24, 2020.

Over that period the epidemic was rapidly developing in Ukraine: the number of people fell ill from March 24 to April 24 increased from 102 to 7,647 (the number of those who died from coronavirus - from 3 to 193 (Worldometer, 2020). Under Resolution of the Cabinet of Ministers of Ukraine No. 211 as of March 11, 2020 On Prevention of the Spread of Coronavirus COVID-19 in the Territory of Ukraine quarantine was introduced throughout the whole territory of Ukraine from March 12 to April 4, and on March 25 for the period till April 24 the emergency situation regime was introduced (Cabinet of Ministers of Ukraine, 2020). Thus, since March 12 mass public events were banned, academic institutions were closed, operation of catering institutions and trade and entertainment complexes was banned; from April 6 staying in public places without a mask, movement in groups exceeding two people, staying in the streets without documents were banned, people above the age of 60 were considered to be the ones in need of self-isolation; regular and irregular passenger transportations were banned.

The interviews were held after a respondent had given his or her informed consent. The questions of the semi-structured interview were related to the above core research problems. Information was moved from audio carriers into transcripts which were later analysed and encoded in manual mode.

All questions were mandatory. The survey was completed by 91 persons aged 18-85 (33 men and 58 women, residing in different cities, towns and villages of Ukraine), who, to the best of their knowledge, as of the date of the survey were not infected with COVID-19. 
The subject matter of analysis consists of transcripts of semi-structured interviews subjected to thematic analysis (Braun \& Clarke, 2006). On the basis of categories identified through thematic analysis a frame was created, through which an individual perceives the threat posed by COVID-19, while configuration of different subcategories shaped up four types of perception, used for data categorisation.

Thematic analysis was conducted by one researcher (Larysa Klymanska). After familiarisation with the data, primary contemplations and initial impressions of the similarities and differences between the answers were recorded. On the basis of the codes developed within the thematic analysis, the system of initial classification was developed from this initial analysis, it being further improved during several iterations. The final block of seven categories was considered as a frame through which an individual perceives the threat of Covid-19, while configuration of different subcategories shaped up four types of perception, used for data categorisation. Ten random per cent of answers were independently encoded using this frame by another researcher (Maryna Klimanska). Since in these cases the agreement was $100 \%$, the answers were not further analysed.

\section{THE STRUCTURE OF THE "COVID-19 RISK" FRAME}

Analysis of the results allowed outline of the very structure of the frame for assessing the risk of Covid-19 (Fig.1.)

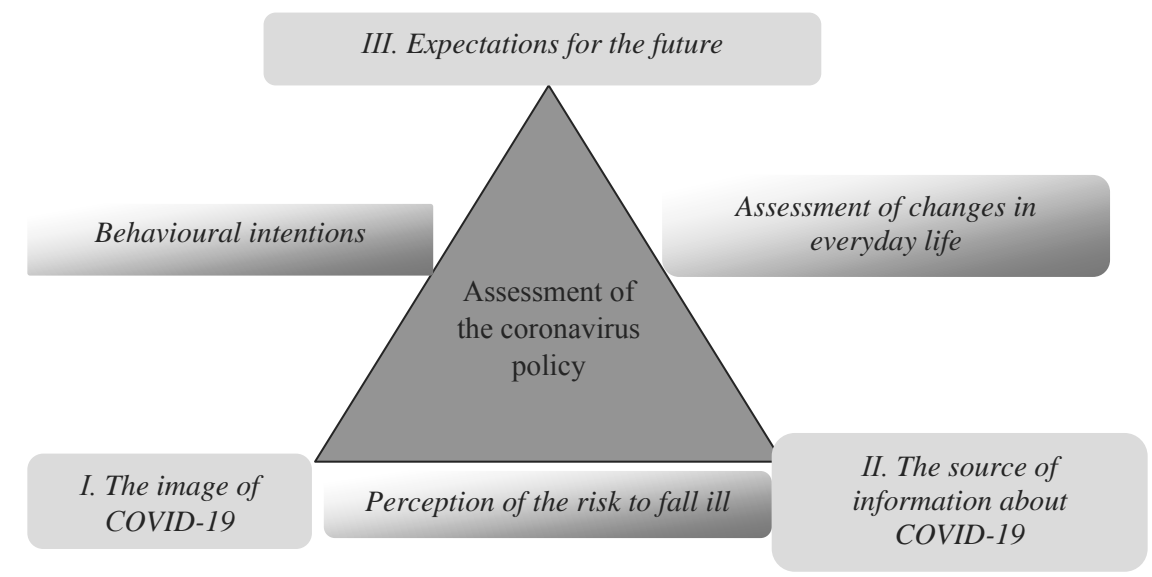

Fig.1. The structure of the "COVID-19 risk" frame Source: own research

The structure of the frame with a relative name "COVID-19 risk" constitutes a triangle of meanings, based on the category "The image of COVID-19" (the informant's ideas-associations concerning what coronavirus is, what are 
the causes of its "pandemic nature", concerning its specificity as compared to other types of viruses and its origin) and the category "The sources of information about COVID-19" (these are answers to the question where informants get information about coronavirus and how far they trust this information, as well as assessment of the degree of impact of this information on the individual's behaviour). The top of the triangle is made up by the category "Expectations for the future" (the informants' statements about changes in the society, the state and in their life after the quarantine). The sides of the frame-triangle (I-III; II-III; I-II) are made up by the categories "Behavioural intentions of the individual in the situation of the COVID-19 pandemic" (ideas about standard behaviour during the quarantine in the situation of the pandemic and, at the same time, readiness to change actual everyday life) (I-III) and "Assessment of changes in everyday life" (evaluative judgments of informants on how far and in what direction everyday life changes in the conditions of the coronavirus infection (II-III), category "Assessment of the coronavirus policy" (evaluative judgments of informants on the correctness, adequacy of political decisions passed in the pandemic situation). The basic category that finally determines possible individual behaviour was the category "Risk perception" (I-II). Risk perception is determined by the fact that the subject assesses the risk, develops ideas, judgments and attitude to the risk, analysing a certain "future" situation, that may contain some negative consequences, and determines it as undesirable or dangerous. Such "situation in the future", in our case, is related to human health, while unfavourable consequences get manifested in health deterioration, disease, or even death. If negative consequences are assessed as possible or considerable, an individual shows self-rescuing behaviour focused on removal or minimisation of the indicated consequences.

\section{RISK PERCEPTION TYPES}

Generalising approaches to defining risk within different approaches, Ortwin Renn came to the conclusion that definitions available in riskology (and let's add ideas) contain three components: first of all, undesirable consequences marked by such categories as "danger," "threat," "harm"; secondly, assumptions on the probability, likelihood of their occurrence; thirdly, ideas on the status of real risk availability, characterised by two standpoints: risk as objective reality; risk as a mental/imaginary structure ("risk is the same as risk perception" (Renn, 1992, p.58; Aven \& Renn, 2010, p.6). The supporters of the first standpoint (that could be called "realistic") consider that risk is an objectively existing factor of human life, regardless of our perception of risk. In particular, that is the opinion of Eugene A. Rosa. The researcher is convinced that risk constitutes objective reality, it exists regardless of our perception and our requirements as to knowledge and subjective assessments of what exactly is under threat and how realistic is the chance of danger appearance (Rosa, 2008, p. 108), therefore, the consequences of risk, regardless of the subject's assessments, always have real, sometimes physical consequ- 
ences. The supporters of the second standpoint, risk perception theories, in particular, Luise Vassie, Paul Slovic, Baruch Fischhoff \& Sarah Lichtenstein (Vassie, Slovic, Fischhoff, \& Lichtenstein, 2005), Mary Douglas, Aaron Wildavsky, Karl Dake (Douglas \& Wildavsky, 1983; Wildavsky \& Dake, 1990) and others, assess risk as a product of social interpretation, as a social construct determined by historical, social and psychological as well as cultural context - subjective interpretation of undesirable events. "The dangers are interpreted as independent variables, while human reaction to them - as dependent ones," - writes M. Douglas (Douglas, 1985, p. 25). It is this standpoint that allows us to assess why and how people opt for this or that behaviour, responding to a possible threat. Using such logic we will try to analyse the ideas of the COVID-19 risk, shown by Ukrainians in our research. The types of risk perception have been split by us in accordance with two criteria that appeared to be critical in the risk perception situation: the level of perception (whether risk is perceived at the level of a specific individual or at the level of the mankind in general) and the nature or background of perception (rationalised or emotionally charged). Thus, we got the following square of perception types or frames (Table 1.) Frame is interpreted by us as a prism through which individuals perceive a situation, a phenomenon, an event.

Table 1

Types of perception

Level of perception Impersonal Personal /

Nature of perception

\begin{tabular}{ccc}
\hline Rationalised & $\begin{array}{c}\text { Virtual risk, potential } \\
\text { danger }\end{array}$ & $\begin{array}{c}\text { Uncertain risk, uncertain } \\
\text { danger }\end{array}$ \\
Emotionally charged & Risk as a potential threat & Risk as a real threat \\
\hline
\end{tabular}

Source: own research

The first frame that can be called "Virtual risk or potential danger" constitutes a combination of impersonal level of perception and rationalised background in which risk is perceived. Within such perception informants told about low level of risk of being infected with the COVID-19 or complete absence of such risk. The logic of their considerations looks as follows: right, this virus exists, right, it spreads all over the world, but I will not be affected by it, I am not afraid of falling ill. To substantiate this standpoint they provided rationalised arguments - good health condition, not belonging to the risk group, good immunity, and healthy life style. Normally, the adepts of such a frame are young people perceiving the very virus in a non-metaphoric manner, without any extra emotions, and for the description of the virus itself and the processes happening to the ill person they often use medical terminology, which also reduces the level of emotional intensity. The risk, in fact, exists, "somewhere", for others, for "elderly people - because, probably, ... their immunity is bad"1 (male,

1 Hereinafter in the text quotations are provided in the format in which they were formulated by the informants 
28 years, gas station operator). The situation with the pandemic is perceived by such individuals as "excessive panic, excessive mass psychosis" (female, 23 years, student), they are irritated by the behaviour of other people who, following the laws of such panic, "are prone to pass some unconsidered decisions, for example, go to supermarket and buy everything they see on the shelves" (female, 23 years, student). Such perception is characterised by differentiated treatment of the sources of information (there are many sources, but their attitude to them and to the information coming from them is selective), understanding of the fact that information is weapons. Assessment of the information received is made not just by the level of the source credibility (usually, the source directly related to medicine is chosen as a credible source), but also by the level of professionalism. Professionally selected information and information that is trustworthy is assessed by the informants sceptically, and they want to have the last word to say. And that last word normally runs as - ...personally for me I don't see any serious risks so far ... everything will be ok, everybody will come to an agreement, we will cope with everything, everything is going to be fine.. ... That is not so scary as depicted.." (male, 28 years, gas station operator); So far I don't see any threat for myself, any serious danger,...well, the devil is not so black as it is painted (female, 23 years, student).

These people perceive themselves as subjects of risk management, they opt for this or that behaviour (action strategy) while responding to a potential threat. They perceive risk as a way of acting in specific conditions. If a correct strategy is chosen, that will finally lead to advantages, to winning over the circumstances. Expectations from the future within such perception are positive: first of all, everything is going to be fine; secondly, if changes occur, these will changes for the better: the situation with coronavirus must affect mankind as a cold shower, for people to come round and to realise that besides profits, money, material values and entertainment there are much more important things in the world (male, 49 years, veterinary doctor).

External guidance on how one should behave during the quarantine is perceived by them as guidance towards such correct strategy as a standard that should be complied with, ... if you are a conscious person, if you follow all the rules that are written not once on the Internet ...: then, I think, the disease can easily pass by (male, 22 years, military man), but not for their favour, but because (and due to the fact) that other people live close to them. Risk assessment is rather related to how and how far that may pose a threat for others. Rationality in the treatment of the situation urges them to critically treat "inadequate actions" taken by other people: whether we speak about buying goods of first priority, or about the fact that some people do not comply with quarantine measures, treat them in a light-headed way, consider that the situation will pass by them or will occur in the form of some flu or running nose ... (male, 49 years, veterinary doctor), or do not comply with the instructions given by the authorities.

Thus, within this frame the risk posed by COVID-19 is perceived as a potential threat, that is as the integrity of possible and really active forces, factors, processes, capable of producing a negative impact on individuals, but not 
in this specific case. The danger certainly has a destructive and destabilising nature, is capable of inflicting some harm on individuals, taking them out of the state of dynamic balance or of complete destruction, but not for me. The leading essential feature of such perception of danger is its potential nature, the assumption on the impossibility of occurrence of such event personally for oneself. Behavioural intentions of such individuals are standard, but since this is the danger not perceived personally, they reserve the right to pass their own decision concerning their behaviour in the situation of further aggravation of the circumstances - well, in my family we have a rather specific attitude to mass media, ...we analyse all the information we get, we treat it critically, therefore even if we read something, we double check it in ten more sources, and only after that we develop our opinion ... (female, 23 years, student), and concerning other people who demonstrate "improper" behaviour.

One more type of perception is the frame "Risk as a potential threat". The type of perception of risk as a potential threat combines impersonal level of perception and its emotionally charged background. In this frame an element of emotional treatment of the situation with coronavirus appears. That is the frame of maximum danger "awful plague" (female, 45 years, child studio editor), but it is the one that is not projected on oneself and is perceived as standing aside. Here understanding of threat already comes into play. If danger is immanently present in the situation with coronavirus as a potential possibility, the threat constitutes its more subjective form appearing as the result of addition of an emotional component to this perception. The threat is a possible danger, but the danger that has reached its limit - it constitutes an utmost manifestation of danger for meeting human needs and interests. That is a direct form of danger. The threat of COVID-19 is perceived as the danger at the stage of transition from potential likelihood into reality, while its potential nature is still present due to the fact that this threat exists for everyone together, and not specifically for the subject.

Fatality can be traced in this frame, but uncertainty as well. For informants it is difficult to say anything specific about this virus, beside the fact that this is a viral disease which spreads too quickly, sometimes they keep to the standpoint ...there are no such people in the world yet who would know where it has come from and what it is ...; possibly, it is of natural origin, or, possibly ... of unnatural (male, 85, pensioner), it is emotions that create such background against which the virus is perceived, therefore, here metaphoric perception of risk is normally present ...there has come a disease for the whole world (female, 73 years, pensioner); a regular bogeyman story (male, 85 years, pensioner); ...we can see that such powerful countries and states that have high economies, that may boast of their best global achievements, ... and they are powerless against such a seemingly small virus implanted in the human organism (female, 45 years, child studio editor). The danger is hyperbolised through emotions, the virus is perceived as a punishment for the mankind for its sinful nature, it poses a threat for everyone, not just for me. This frame operates with such categories as "population," "mankind": disease - it creates risks for all people (female, 20 years, student), predicting 
development of the situation in general, and not for oneself personally: that is a very serious ordeal for all people (female, 45 years, child studio editor), voicing predictions as to the fact that people must go through this ordeal ...80\% of the population will contract the disease, 6-7\% will die. Mankind must experience all that. Once we have appeared, we have to go through that (male, 52 years, not indicated).

The sources of information for informants with such frame are both traditional and modern media, but the level of their credibility is different. They mainly trust official information and express their doubts as to whether informal information should be trusted, in particular the one showing everything in the negative light only -...I can see that there is a lot of information in Facebook social media, links and different texts about these diseases. They are ... highlighted in the negative form, though the picture, in fact, is not that negative (female, 20 years, student) - and the conclusion "one needs to trust only official and validated data. I take information from the official website of the Ministry of Health of Ukraine. Due to such specific attitude to information (lack of trust, first of all, in negative information) such informants also have a specific attitude to the groups that are the most vulnerable in this situation: First of all, the most vulnerable are the people who fail to observe not 'personal hygiene', but 'information hygiene'. One should not panic, one should not buy buckwheat and toilet paper in large amounts as well. But it is difficult to convey the idea of the quarantine importance to pensioners since they have their own argument to that: 'I have lived through harder times in my life! (female, 18 years, student); ...I think the least affected will be the people who do not trust any mass information, but lead a healthy life style, do not catch a cold, care about their health (male, 85 years, pensioner).

Official sources of knowledge about COVID-19, official information that has credibility shape up a special attitude of such people to the situation with observing the norms over the period of quarantine and behavioural intentions: I am not afraid since, in fact, I keep to the quarantine regime more or less and try to stay at home (female, 20 years, student), we don't know anything, we are small people - that's why we do as we are advised to do (male, 45 years, head of the utility enterprise security service); ... we listen to TV. We do what they say (female, 73 years, pensioner). The logic behind that is very simple: compliance with the norms recommended by official sources ensures security in this situation, and since I follow the norms, and I am not going to be affected by this threat. That is the explanation of impersonal attitude to coronavirus is different than in the previous case. Assessing information about the spread of coronavirus, without understanding and even trying to understand what is happening: I don't trust anyone, I don't know anything well enough (female, 52 years, entrepreneur), individuals rely on external instance that may punish, or may grant a pardon. God may come as such instance, or political authorities. And while there are no claims to God, the authorities have not envisaged, failed to counteract, at best, and at worst - have created such a situation themselves - ... in my opinion, all this situation has been created artificially. Probably, somebody needed it. In each country there are people who use it to their benefit, and after all this finishes, in some time we will probably come to know something (female, 52 years, entrepreneur); The 
danger, I guess, is high, since our state does not provide us with anything, even with elementary protective means, though writes off large amounts of money for that (male, 44 years, builder).

Thus, the frame "Risk as a potential threat" shifts this risk in perception from the "potential danger" status to the status of "potential threat", adding an affective component to perception. The likelihood of occurrence of such threat is considered to be absolutely realistic, but it is perceived not in a personalised way, rather as something posing a threat to mankind in general. Behavioural intentions of informants with this type of perception fully fit the wish to comply with official recommendations, since they, to a certain extent, seemingly guarantee security.

One more type of perception marked as "Uncertain risk or uncertain danger" combines personal perception with rationalised nature.

Uncertainty stands for an incomplete or inaccurate idea about the values of different parameters in the future, that may result from different reasons and, first of all, may be caused by incomplete or inaccurate information about the conditions of decision enforcement, including related losses and results. The key difference between risk and uncertainty lies in the plane of possibility/ impossibility of their measurement. Uncertainty cannot be measured, while risk is subject to assessment, hence, it can be managed. Therefore, the name "uncertain risk" is paradoxical: on the one hand, risk is recorded, and, on the other hand, it is impossible to measure and determine it as of the present day: which means that you live for a day and you don't know absolutely anything about what tomorrow will be like, and you expect something not good, but vice versa, something bad again (female, 49 years, medical nurse). Such type of coronavirus threat perception is characteristic of people with a medical frame of situation perception, who are not always medical staff. In the discourse of such informants there are many medical terms (viral disease, high mortality rate, coronavirus is an acute respiratory infection characterised by a quick course and a high level of contagiousness (male, 23 years, emergency doctor); lung affliction, pneumonia, difficulty in breathing, fatigue... (female, 46 years, courtroom secretary). That is a rationalised attitude to risk without emotional layers, instead it is personalised due to either belonging to the medical profession, or due to some interest in medical knowledge for different reasons. That is realisation of risk, but at the same time understanding of the fact that this risk cannot be predicted since modern medicine does not yet possess sufficient knowledge about it - we are afraid of coronavirus, since we are afraid of something unknown. That is a new strain, poorly studied yet. While we realise what flu is and what it can bring about, we don't know yet what coronavirus can bring about. Since that is the virus that can change, mutate (female, 25 years, dentist).

People with this type of perception show a rather specific attitude to information. First of all, that is a critical attitude to information provided by non-specialised mass media - ... having a large resource for affecting population, they do not realise their influence and spread incorrect information or information in the incorrect format ... following the type ... keep calm, only old people will die (male, 23 years, emergency 
doctor); information in mass media is... superficial, since there is no specific statistical data on the disease (female, 47 years, health care professional), therefore, among all the credible sources they point out the Ministry of Health and the WHO, and to be more specific - doctors-virologists have the most information, these are people with a narrow specialisation, who know a lot about the field. I think I still trust them the most (female, 23 years, pharmacist). Treatment of risk by such informants is purely instrumental - like in any viral disease: ... in viral diseases there always exists the danger of falling to it, ... at work I communicate with people, and that is already a risk (female, 47 years, health care professional); my attitude to danger, well, I think that... there is some danger, but it is no more serious than with other diseases that are also wide-spread in Ukraine (male, 23 years, emergency doctor). The medical frame is characterised by an absolutely sober-minded treatment of standard behaviour and its chances of saving a person from a disease: ...I try to keep to the recommendations given to us. At work I put on a mask that needs to be changed every hour and a half or every hour since it then becomes dangerous for myself, since when I breath in the mask for more than two hours I will already be breathing in those harmful bacteria back into the organism, and that will also be bad. Well, and we need to often wash our hands, or to process them with disinfectants, in public places we need to ensure the recommended distance between people, a metre and a half or two metres. Well, these are the rules I obey (female, 47 years, health care professional). The blame for the quick spread of virus is laid on people's irresponsibility: A man who worked in Italy comes back to his family - he meets his wife, children, grandchildren, parents. He is in contact with 15 people. In a week he falls ill, and all those people have already left their houses and been in contact with other people. That is how it all starts. Our people don't realise the seriousness of this disease and treat it in a light-headed way. We have an example of Italians who neglected quarantine. And now we can see the consequences (female, 25 years, dentist).

Performance of functional duties in the quarantine period stands for daily life of medical staff, therefore, behavioural intentions of such people have not changed, the same as their professional duties: Certainly, all my daily business remains the same, which means that I go to work according to my schedule, but I have just limited my leisure time. That is work at home remains, work at the workplace remains, and I personally don't feel any substantial difference as far as some duties are concerned (male, 23 years, emergency doctor). Certainly, what health care professionals expect in the future is related to the treatment of medicine - at the state level: It would be good to believe that... our authorities will come to understand that medicine is the last pillar in the fight with diseases and will start treating both medical staff and medicine in general in a different way (male, 23 years, emergency doctor), of health care professionals - at the level of ordinary people: And people's attitude to doctors will change...., I think. If they survive, of course (male, 23 years, emergency doctor); of themselves: it is worth following personal hygiene, and ... washing hands could start not just in 2020 (male, 23 years, emergency doctor).

In this frame risk perception exists, in spite of the uncertainty, realisation of the finiteness of this situation - the disease starts, and it will be over. And, as 
always, what starts, must finish, and people will be back to the life they lived in before the epidemic (female, 47 years, health care professional).

Thus, within the frame "Uncertain risk, uncertain danger" it is uncertainty that is perceived as the source of risk. The likelihood of such risk occurrence is perceived in a personal and rationalised way due to "proximity" to the field of virus spread in the social sense. Uncertainty, imperfection of knowledge about coronavirus is the factor that causes behavioural intentions of the informants, who, due to the "medical nature" of their perception, project the need for correct treatment of preventive prescriptions for the "disease".

The last type of risk perception - "Risk as a real threat" - combines personal attitude and emotional charging of perception.

This type of threat perception can be considered to be a direct opposition of the frame "Virtual risk, potential danger". Informants' answers are characterised by high level of risk perception. As one of the informants has aptly put it - for me "life has not stopped, but it is as if ... on standby" (female, 18 years, student). As a rule, such perception has got a personal colouring (that poses a threat directly for me ...), the causes of what has happened are related to external sources that have created the threat or reinforce it. The most wide-spread substantiations include the following - the Chinese have "finally landed themselves" in the new virus; established a secret laboratory from which the "virus" leaked; other people show improper behaviour, insufficient hygiene, therefore contact with others was perceived as a factor reinforcing individual risk of viral infection: Knowing how many people got back from work abroad, and not all of them tell about this, information is concealed, and then disclosed, when symptoms appear, or from the date when they already had contacts with their relatives, acquaintances and generally people around them, in the shop, in transport, on their way. Such irresponsibility can be traced with people (female, 47 years, shop assistant). The very COVID-19 within this frame is perceived metaphorically - that is the evil, that is the divine scourge: I guess God has closed us in our houses for us to understand, to reconsider our lives, reassess life values (female, 45 years, housewife), that is rejuvenation of the planet as the result of getting rid of elderly people, that is a litmus paper that has shown how much in decay our medical system is, how much mankind has already polluted the planet. The words "heavy," "awful," "frightening," "horror," "tragedy," "awful threat" are sometimes repeated tens of times in the texts of interviews: it is scary, scary that side by side with you there may be passing a person who is a carrier of the infection that has caused so many problems (male, 20 years, student). Even the first reaction to coronavirus occurrence with such informants differs from the ordinary "China is far away, this will not affect us": a great fear has arisen ... a concern that this may ... affect our country as well, and that will be spreading en masse (female, 45 years, housewife). That is how the risk-threat posed by coronavirus is perceived by people who have some health problems (they realise their belonging to the most vulnerable categories within the indicated virus) regardless of age: Due to my health condition I must not forget about sanitation, be careful since I know that I will probably not survive, or it will be hard for me to get through the disease since I have problems with 
my lungs (female, 50 years, hotel administrator); I am very much concerned not to fall ill since I have bronchial asthma and that is directly related to breathing problems ...(female, 18 years, student). That is, age in this case can possibly not be the marker determining belonging to the intrapersonal risk perception. Attitude to information obtained by such people from different sources can be characterised as "with a suspicion" - we are not told everything, the situation, in fact, is much worse that we are told, the real number of deaths is concealed from us for us not to panic. The ideas about the future are either generally non-existent (let this horror finish first), or pessimistic. As far as behaviour is concerned, such people are hypernormative, they follow all possible recommendations, that helps them overcome horror: I am very serious about not contracting the disease myself and not transmitting it to others, therefore I do my best to minimise the danger (male, 20 years, student). In their daily behaviour people with such perception of threat try to act sometimes even more rigidly than recommended, they keep distance at home with their family members, try to process all foodstuffs from the supermarket with disinfectants, even toilet paper is processed with a disinfectant, though nobody has ever told them to do so. Their plan is to even intensify preventive measures - ... we will be..well..particularly, if this threat grows in intensity in our city, we will try to further intensify some security measures in our family (female, 45 years, housewife).

Thus, within the frame - "Risk as a real threat" - the risk of coronavirus is perceived on a personal level with high emotional intensity, as a real, and not imaginary threat, with the assumption of likelihood personally for oneself, and not just for mankind in general. Perception of the real chance to fall ill is combined with pessimistic forecast for the future and with hypernormative treatment of the recommended safe behaviour measures.

\section{CONCLUSIONS}

According to the approach of the World Health Organization, all stakeholders must be entitled and have the opportunity to express their opinions and advantages, raise the issues of concern, as well as influence knowledge and attitude that are necessary for looking for the best solutions in the risk area (Theakston, 2013). In fact, that presupposes the need to reject the traditional "expert" risk management model and shift to the socially-guided approach, within which such risk aspects are analysed as "risk perception," "socially permissible level of risk" and "social risk acceptance." Risk must be studied in the context of existing values of society, while its management should be accompanied by the general state support at all stages. The dilemma as to the right to risk and independent decision-making vs. irrational subjectivity of individual criteria of risk assessment as an a priori risk of the threat underestimation must be settled via detection of hidden attribution mistakes for the sake of preventing real danger. It is necessary to apply qualitative research methods in the conditions of high level of uncertainty resulting from lack of objective know- 
ledge about the actual virus properties in order to trace the lens and prisms of information refraction, which determine specific frames of its interpretation as actual behaviour pre-disposition. Identification of hidden context and content is important at the very beginning of the epidemic development, as well as at all further stages, since it enables the tracking of objective behaviour-related threats and risks based on irrational beliefs. The typology of ideas, frames about risk in the conditions of the COVID-19 pandemic requires further specification and validation within a quantitative research. Combination of qualitative and quantitative studies will enable us to determine the content and strategies of anti-epidemic measures as well as to implement efficient risk communications for successful inclusion of all stakeholders in risk management, the key to transition from 'informing' to 'involvement.'

\section{REFERENCES}

[1] Aven, T., \& Renn, O. (2010). Risk management and governance: concepts, guidelines and applications. Heidelberg. New York: Springer Science \& Business Media.

[2] Bavel, J. J. V. et al. (2020). Using social and behavioural science to support COVID-19 pandemic response. Nature Human Behaviour, 4, 460-471.

[3] Behaviour fuels, and fights, pandemics. (2020). Nature Human Behaviour, 4, 435, https://doi. org/10.1038/s41562-020-0892-z

[4] Betsch, C. (2020). How behavioural science data helps mitigate the COVID-19 crisis. Nature Human Behaviour, 4, 438. https://doi.org/10.1038/s41562-020-0866-1

[5] Braun, V., \& Clarke, V. (2006). Using thematic analysis in psychology. Qualitative Research in Psychology, 3(2), 77-101.

[6] Cabinet of Ministers of Ukraine. (n.d.) Постанова Кабінету Міністрів Украӥни №211 від 11 березня 2020 року «Про запобігання поширенню на території України коронавірусу COVID-19». [Resolution of the Cabinet of Ministers of Ukraine No. 211 as of March 11, 2020 "On Prevention of the Spread of Coronavirus COVID-19 in the Territory of Ukraine"]. Retrieved July 22, 2020, from https://www.kmu.gov.ua/npas/ pro-zapobigannya-poshim110320rennyu-na-teritoriyi-ukrayini-koronavirusu-covid-19

[7] Douglas, M. (1985). Risk acceptability according to the social sciences. New York: Russell Sage Foundation.

[8] Douglas, M., \& Wildavsky, A. (1983). Risk and culture: an essay on the selection of technological and environmental dangers. Berkeley and Los Angeles: University of California Press

[9] Erikson, S. (2020). Pandemics show us what government is for. Nature Human Behaviour,4, 441-442.

[10] Haletska, I., Klymanska, L., \& Klimanska, M. (2020). Quarantine April in Ukraine: thoughts, experiences, behaviour faced with the threat of COVID-19. Psychological Journal, 6 (5), 18-36.

[11] Johnson, G. A., Vindrola-Padros, C. (2017). Rapid qualitative research methods during complex health emergencies: A systematic review of the literature. Social Science and Medicine, 189, 63-75.

[12] Kahneman, D., Slovic, P., \& Tversky, A. (1982). Judgment under uncertainty: Heuristics and biases. Cambridge, U.K.: Cambridge University Press.

[13] Lupton, D. (1999). Risk. London: Routledge.

[14] Oosterhoff, B., \& Palmer, C. (2020). Psychological Correlates of News Monitoring, Social Distancing, Disinfecting, and Hoarding Behaviors among US Adolescents during the COVID19 Pandemic. PsyArXiv, March 23. https://doi.org/10.31234/osf.io/rpcy4

[15] Renn, O. (1992). Concepts of risk: a classification. In: S.Krimsky \& D. Golding (Eds.) Social theories of risk (pp.53-79). Westport, CT: Praeger.

[16] Rosa E. A. (2008) White, black and grey: Critical dialogue with the international risk governance council's framework for risk governance. In: O. Renn \& K. Walker (Eds.), Global risk 
governance: concept and practice of using the IRGC framework (pp.101-118). Heidelberg: Springer Netherlands

[17] Sharot, T. (2011). The optimism bias. Current Biology, 21 (23), R94-R945.

[18] Sociological Group "Rating". (2020). Україна на карантині: моніторинг суспільних настроїв [Ukraine under quarantine: monitoring of public moods]. Retrieved July 22, 2020, from http: //ratinggroup.ua/files/ratinggroup/reg_files/rg_ua_cc_032020_press.pdf

[19] Soper, G. A. (1919). The lessons of the pandemic. Science, 49 (1274), 501-506.

[20] Stanley, M., Barr, N., Peters, K., \& Seli, P. (2020). Analytic-Thinking Predicts Hoax Beliefs and Helping Behaviors in Response to the COVID-19 Pandemic. PsyArXiv. March 30. https:/ / doi. org/10.31234/osf.io/m3vth

[21] Teti, M., Schatz, E., \& Liebenberg, L. (2020). Methods in the Time of COVID-19: The Vital Role of Qualitative Inquiries. International Journal of Qualitative Methods. https://doi. org/10.1177/1609406920920962

[22] Theakston, F. (Ed.). Health and environment: communicating the risks. (2013). Retrieved July 22, 2020 from http:// www.euro.who.int/_data/assets/pdf_file/0011/233759/e96930.pdf

[23] Vassie, L., Slovic, P., Fischhoff, B., \& Lichtenstein, S. (2005). Facts and Fears: Understanding Perceived Risk. Policy and Practice in Health and Safety, 3:sup1, 65-102.

[24] Wildavsky, A., \& Dake, K. (1990). Theories of Risk Perception: Who Fears What and Why? Daedalus, 119(4), 41-60.

[25] Worldometer. (n.d.) [COVID-19 coronavirus pandemic]. Retrieved July 22, 2020, from https://www.worldometers.info/coronavirus/country/ukraine/ 